UDC 577

\title{
Structural and functional significance of microsatellites
}

\author{
T. Sjakste ${ }^{1}$, N. Paramonova ${ }^{1}$, N. Sjakste ${ }^{2,3}$ \\ ${ }^{1}$ Genomics and Bioinformatics, Institute of Biology University of Latvia \\ 3, Miera Str., Salaspils, Latvia, LV-2169 \\ ${ }^{2}$ Faculty of Medicine, University of Latvia \\ 19, Raina blvd., Riga, Latvia, LV-1586 \\ ${ }^{3}$ Latvian Institute of Organic Synthesis \\ 21, Aizkraukles Str., Riga, Latvia, LV-1006 \\ Nikolajs.Sjakste@lu.lv
}

\begin{abstract}
Here we review literature data on impact of microsatellite repeats on DNA and chromatin structure and the results of studies on association between the length of microsatellite repeats and predisposition to pathologies. The DNA secondary structure is modified in microsatellite sites, the repeats favour formation of Z-DNA, hairpins, triplexes and quadruplexes. The chromatin structure and chromatin loop organization are also modified in microsatellite sites. The data of association studies are classified according to the localization of the microsatellite: in the gene promoter, in exon 1 part coding the signal sequence, in the gene introns, coding areas and 3'-UTRs.
\end{abstract}

Ke y w o r d s: microsatellite repeats; chromatin, human diseases; promoter; intron; exon.

Microsatellites (MS) are repeating sequences of 2-6 base pairs of DNA distributed throughout the genome [1] and widely used as molecular markers in genetics, for kinship, population and other studies. Variability of the microsatellites forms a potent tool for individual characterization of genomes. The microsatellite repeats are able to mutagenize the genomes of humans and are therefore poised to dynamically alter the human genomic landscape across generations [2].

Microsatellites remain highly informative and useful measures of the genomic variation for linkage and association studies, as microsatellites have a greater allelic diversity than biallelic SNPs. A singlestep expansion or contraction of the tandem repeat on the background of ancestral SNP haplotypes can break up common haplotypes, leading to a greater haplotype diversity [3].

Although mostly used as structural genetical markers microsatellites perform several functions in ge- nome which are still far from being completely understood. Peculiarities of the DNA and cell nucleus structure in microsatellite areas will be analysed first.

\section{DNA secondary structure}

Repeating short sequences in the microsatellites enable the formation of altered secondary structure of the DNA molecule. Types of the altered secondary structure are graphically presented in Fig. 1. The formation of altered secondary structures like hairpins, cruciform structures, quadruplexes and triplexes is considered to be the main mechanism for passage of the "length threshold" in triplet expansion diseases [4].

$Z-D N A$. Several dinucleotide repeats are able to undergo transitions from B-DNA to Z-DNA via intermediate forms [5]. The GAC trinucleotide in cartilage oligomeric matrix protein normally should contain five repeats; expansion by one repeat causes

(C) 2016 T. Sjakste et al.; Published by the Institute of Molecular Biology and Genetics, NAS of Ukraine on behalf of Biopolymers and Cell.

This is an Open Access article distributed under the terms of the Creative Commons Attribution License (http://creativecommons.org/licenses/by/4.0/),

which permits unrestricted reuse, distribution, and reproduction in any medium, provided the original work is properly cited 

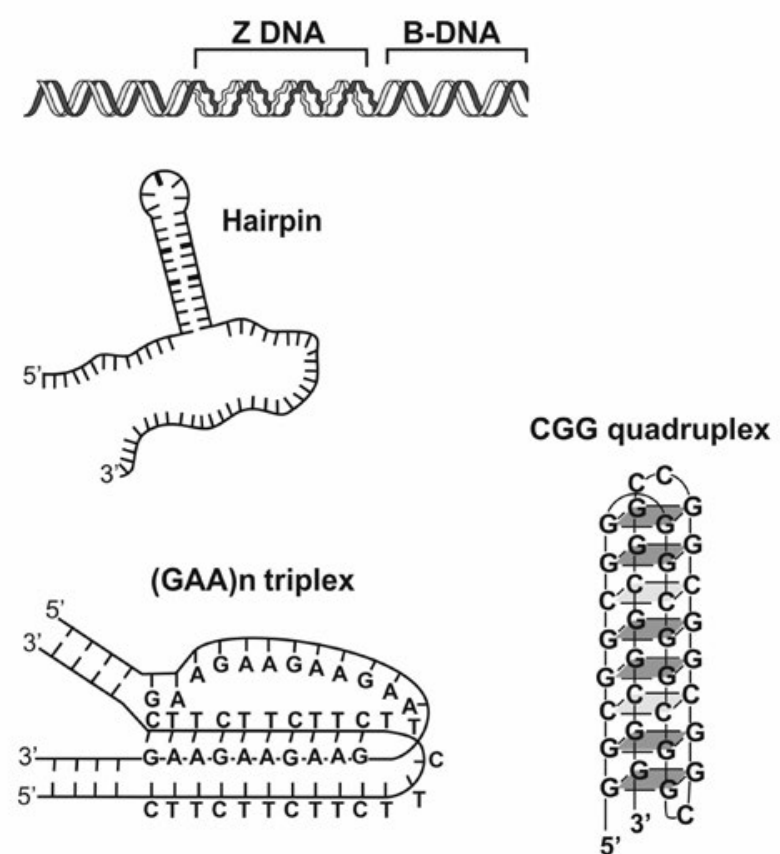

Fig. 1. Possible modifications of the DNA higher order structures formed by microsatellites (according Smith, 2008).

multiple epiphyseal dysplasia, whereas expansion by two repeats or, remarkably, deletion of one repeat causes pseudoachondroplasia. The repeats can form Z-DNA and three other altered secondary structures [6]. Left-handed Z-DNA is formed from $\mathrm{d}(\mathrm{GT}) 17$ and $\mathrm{d}(\mathrm{CG}) 17$ repeats under the topological tension of negative supercoiling and enables the interaction of these microsatellites with intermediate filament proteins [7]. Ability to form Z-DNA structures is crucial for the interactions of binding proteins like human editing enzyme ADAR1 with DNA [8]. Expanding CGG runs, responsible for the development of fragile $\mathrm{X}$ chromosome syndrome, adopt a left-handed Z-DNA structure. It is supposed that Z-DNA may be formed by long, expanded CGG stretches that become hypermethylated; this would inhibit transcription resulting in a disease [9]. The formation of Z-DNA conformation by CCG repeats is facilitated by $\mathrm{Al}$ ion binding, concentration of these ions increased in the patients [10]. Z-DNA and cruciform structures are formed also by $\mathrm{CTG} \cdot \mathrm{CAG}$ repeats of the myotonic dystrophy locus [11]. The temporal formation of left-handed helix Z-DNA might be a cause of the increased sensitivity of microsatellites to the chemical mutagens [12].

Hairpins. Trinucleotide repeat expansion is the cause for many known human congenital neurological and muscular disorders like Huntington's disease, fragile X syndrome, and Friedreich's ataxia. The stable secondary hairpin structures formed by trinucleotide repeat may trigger fork stalling during replication; causing DNA polymerase slippage and trinucleotide repeat expansion. Thus, the hairpin formation appears to be a main step in pathogenesis of these diseases. The formation of hairpins by trinucleotide microsatellites was proven experimentally in biophysical studies; it was revealed that CGG repeats form intrastrand hairpins consisting of mismatched base pairs that promote primer-template slippage during DNA replication, these sites are favourable for binding DNA intercalating drugs like actinomycin D [13]. The hairpins formed by the short intronic repeats enable the formation of the circular RNAs, necessary for mRNA processing [14].

The hairpins formed by the compound microsatellites consisting of two or more individual microsatellites are considered to be hot-spots for recombination in plant viruses [15]. Stable secondary hairpin structures resulting in trinucleotide repeat expansion causing DNA polymerase slippage and trinucleotide expansion are removed by special helicases aimed at resolving theses hairpins [16]. The (CAG)4 repeat connected with Huntington's disease forms stable hairpins, unlike the related (CGA)4 which adopts several conformations in solution [17]. In the case of the human fragile $\mathrm{X}$ mental retardation 1 gene (FMR1; HGNC:3775), a (CGG)n trinucleotide can cause either fragile $\mathrm{X}$ syndrome or fragile $\mathrm{X}$-associated tremor/ataxia syndrome (FXTAS) depending on the number of repeats formation of hairpins and R-loops during transcription of the repeats that is considered to be the cause of altered gene expression in these diseases [18]. On the other hand, hairpins in the expanded trinucleotides can serve as a target for specially designed alkylating drugs [19]. Hairpins are possibly formed also by other types of 
microsatellites, as bioinformatics analysis of possible influence of the repeat number of several microsatellite alleles in the intron 6 of the human proteasome core particle PSMA6 gene and four other microsatellites localized upstream in human Chromosome 14q13.2 revealed that in two of the studied microsatellites such changes were quite possible. In the HSMS602 marker, a increase in the CAA repeat number up to 10 triggers the changes in DNA secondary structure different from that of (CAA)7 and (CAA) 8 alleles. In the HSMS006 microsatellite an increase in the TG repeat number from 17 to 18 is followed by a change in the hairpin structure [20]. Microsatellites identified in the vimentinbinding DNA also are capable to form hairpins [21].

Triplex structures. The triple-helix formation is believed to be important in numerous fundamental genetic processes like regulation of transcription and replication, genetic recombination of homologous sequences and chromosome folding. The short repeated sequences like nonamer d(GCGAATTCG) and decamer d(GGCCAATTGG) form triplex structures that could be crystallized and subjected to $\mathrm{X}$-ray diffraction study [22]. The triplexes formed by microsatellites $\mathrm{d}(\mathrm{A}(\mathrm{GA}) 20$ (TC)20T) and d(GA) 20 and d(TC)20 interact with the intermediate filament proteins via partially unwound structures [23]. The highly repeated Drosophila melanogaster AAGAGAG satellite sequence present in centromeres of all chromosomes of the fly forms a pyrimidine triple helix containing $\mathrm{T}$ A $\mathrm{A}-\mathrm{T}$ and $\mathrm{CCu} \mathrm{G}-\mathrm{C}$ base triplets, stabilized by copper ions in the amounts close to in vivo concentrations. Formation of the triplex helices could be detected in vitro by means of infrared spectroscopy [24]; it is supposed that such structures are formed in centromeric areas of chromosomes in living cells. Among human inherited diseases the triplex formation is well-documented for Friedreich's ataxia (FRDA), the autosomal neurodegenerative disorder where a large purine GAA repeat in the $F X N$ gene, forming a triplex structure, is known to inhibit the expression of frataxin protein. A wide human genome scanning performed by Singh and Rajeswari $[25,26]$ revealed existence of numerous purine-rich microsatellite repeats in the genes related to brain function. It is supposed that inhibition of expression of these genes due to the triplex formation is important in pathogenesis of autism, Alzheimer's disease, schizophrenia, epilepsy, mental retardation, Parkinson's disease and brain tumours $[25,26]$. Besides the triples structure, the FRDA GAA-TTC repeats are capable of forming various alternative structures, including a parallel GAA TTC duplex in equilibrium with the antiparallel Watson-Crick GAA·TTC duplex [27].

G-qundruplexes and I-motifs. The telomeric repeats situated in overhanging single-strand structures on telomeres can also form unusual structures. A guanine-rich repeats like $\mathrm{H}-\mathrm{Tel}$, formed by four consecutive repeats of the human telomeric sequence, d(AGGGTTAGGGTTAGGGTTAGGG), can assume different monomolecular G-quadruplex topologies depending on the type of cation present in solution and their concentration, the association process is affected by partially unfolded antiparallel structures [28]. Indeed, these repeats can form several types of unusual structures including G-triplex, misfolded G-quadruplex and typical G-quadruplexes, the formation of different structures depends on number of repeats and length of the loops [29]. The telomere-targeted drugs are selected on the basis of binding to G-quadruplexes [30].

The G- quadruplexes are formed also in double stranded DNA. The G4C2 hexanucleotide repeat expansion, located in the first intron of the C9ORF72 gene, represents a major genetic hallmark of amyotrophic lateral sclerosis and frontotemporal lobar degeneration. Using nuclear magnetic resonance and circular dichroism spectroscopy it was shown that DNA G4C2 with varying number of repeats $d(\mathrm{G} 4 \mathrm{C} 2)$ $\mathrm{n}$ forms planar guanine quartets characteristic of G-quadruplexes, the latter are non-canonical DNA structures stabilized with sodium or potassium cations. These DNA G-quadruplexes can be formed inter- and intra-molecularly in either parallel or antiparallel orientation, based on $\mathrm{d}(\mathrm{G} 4 \mathrm{C} 2)$ sequence length. An important role in pathogenesis of amyotrophic lateral sclerosis and frontotemporal lobar de- 
generation is ascribed to structural changes in DNA linked to a number of the repeats [31]. The topology study of a G-quadruplex formed by d(G4C2)4, which was performed by another group showed that it favoured a monomeric fold and formed a chairtype G-quadruplex with a four-layer antiparallel G-tetra core and three edgewise loops, which is distinct from the known structures of chair-type G-quadruplexes. These structures lead to abortive transcripts [32]. Interestingly, the reverse DNA strand, consisting of an extremely C-rich (C4G2)n sequence also forms unusual structures, so-called I motifs. I-motifs consist of two parallel duplexes in a head to tail orientation, the strands of which are held together by hemiprotonated C-C pairs; these can be formed intra- or inter-molecularly [33]. The recently published crystal structure of a CCG repeat sequence shows that two dT(CCG)3A strands can associate to form a tetraplex structure with an I-motif core containing four $\mathrm{C}: \mathrm{C}(+)$ pairs flanked by two $\mathrm{G}: \mathrm{G}$ homopurine base pairs as a structural motif. The tetraplex core is attached to a short parallel-stranded duplex. Each hairpin itself contains a central CCG loop in which the nucleotides are flipped out and stabilized by stacking interactions [34]. Plant retrotransposon long terminal repeats which share common features with microsatellites are also capable of forming G-qudruplexes [35]. The c-myc gene promoter contains the 27-nt purine-rich strand (Pu27) formed by six guanine stretches, five of which contain three or four guanines per stretch, thus meeting definition of a microsatellite, which can form G-quadruplexes [36]. The formation of hairpin and tetrahelical structures by a $\mathrm{d}(\mathrm{CGG})$ trinucleotide repeat sequence is thought to cause expansion of this sequence and to engender fragile $\mathrm{X}$ syndrome. It was shown that human Werner syndrome DNA helicase unwinds the G-quadruplex structures of d(CGG)7 [37]. Among numerous repeated sequences interacting with vimentin in mouse cells via the G-quadruplex structures several share some features with microsatellites [38].

Chromatin structure. In triplet-expanding the expanded microsatellites are mostly hypermethyl- ated and hypoacetylated, indicating heterochromatic nature of their regions [39]. The expanded CTG.CAG repeat tracts are among the strongest of known histone-binding sequence elements, and cause drastic alterations in the local chromatin structure. These sequences adopt tightly condensed heterochromatin configurations in vivo that mediate the gene-silencing effects underlying the pathogenesis of both FRDA and FRAXA. The attenuation of gene expression by the expanded GAA - TTC repeats is associated with the hypoacetylation of histones $\mathrm{H} 3$ and H4 [40]. One of the causes of transcriptional deficiency in Friedreich ataxia is an extension of repressive chromatin from the expanded GAA in intron 1 to the upstream regions of the $F X N$ gene, involving the $F X N$ transcriptional start site. The major $F X N$ transcriptional start site, is normally in a nucleosome-depleted region, however it is rendered inaccessible by altered nucleosome positioning in FRDA [41]. However the GAA repeat itself should be depleted of nucleosomes due to a poor ability to form complexes with histones [42]. An inability to form nucleosomes arises from the formation of duplex and triplex structures in the repeat [43]. On the contrary, the $\mathrm{CAG} \cdot \mathrm{CTG}$ repeats expanded in the Huntington disease form nucleosomes effectively. In case the repeat number is normal, the formation of chromatin is regulated by adjacent htt gene sequences, the control is lost when the repeat number exceeds the normal size [44]. The human MAR 1-68 containing AT repeats is nucleosome-free [45].

Nuclear matrix attachment and chromatin loop organization. Microsatellites are known to form the nuclear matrix anchorage sites $[45,46]$ especially the tissue specific matrix attachment sites [47]. In Friedreich's ataxia, the expanded GAA repeats in intron 1 increase the $F X N$ localization at the nuclear lamina, a structural component of the nuclear matrix [48]. In fascioscapulohumeral muscular dystrophy (FSHD) a partial deletion of integral numbers of D4Z4 repeats leads to the weakening of DNA and nuclear matrix bonds, and loss of one matrix attachment site, strength of DNA-matrix interactions depends also on the epigenetic factors $[49,50]$. 
Interestingly, the GAA repeat-containing RNAs, a recently described class of non-coding RNAs, transcribed from complementary microsatellites are localized within the nuclear matrix [51].

Enhancers and silencers. Microsatellites appear to be the important components of insulators [52], silencers [45, 53] and enhancers [54]. In the Drosophila GATA simple sequence, the repeats function as enhancer blocker boundaries [55].

Thus, microsatellites form peculiar structures at the DNA and chromatin level, which inevitably should modify gene functions and lead to the pathology development in some cases. In the following part of the review we shall analyse an association of microsatellite polymorphisms with diseases depending on localization of the repeats in the genes. Triplet expansion diseases and microsatellite instability in tumours will not be analysed, as these questions are intensively reviewed elsewhere [56, 57].

Promoter microsatellites. The number of GA repeats in promoter of the SOX5, MECOM, and $G A B R A 3$ genes determines transcriptional activity of these genes, similar repeats were found in promoters of numerous other human genes $[58,59]$. The rodent Sry gene contains a CAG microsatellite, which could accelerate evolution in the taxon [60]. An ability of promoter microsatellites to form unusual secondary structures like Z-DNA and H-DNA is crucial for transcription control performed by these repeats [61]; microsatellites near the transcription start are conserved evolutionary [62]. A polymorphic regulatory Z-DNAforming microsatellite of a (GT/AC)n repeat localized in the promoter of the human solute carrier family 11 member 1 (SLC11A1) gene determines the predisposition to infectious inflammatory diseases and cancer. The length and composition of microsatellite repeats influence the chromatin remodelling and accessibility by transcription factors [63]. For example, a polymorphic TG dinucleotide repeat at $-68 \mathrm{bp}$ in the promoter of the thyrotropin-releasing hormone receptor (TRHR) gene is associated with essential hypertension. A shorter allele of this repeat manifests a higher affinity to transcription factors compared to the longer allele [64]. The hypoxia-inducible Factor 1 (HIF-1) regu- lates allelic variation in SLC11A1 expression by binding directly to the microsatellite during the macrophage activation [65]. Z-DNA conformational sequence structures within the promoter of the $n N O S$ gene have the potential to enhance or repress gene promoter activity affecting endogenous NO synthesis and potentially result in diseased states [66]. The Z-DNA sequence element Z1 [(CA)10(CG)8] in the promoter region in the rat nucleolin gene inhibits the promoter activity independently of location and orientation [67].

The most common allele of the MS marker in STAT4, the STAT4-MS1-254 allele, located in the 5' flanking region of the gene is significantly associated with sarcoidosis [68]. The length changes of microsatellites within promoters and other cis-regulatory regions can also change level of gene expression; they are linked to abundant variations in cis-regulatory control regions in the human genome [69]. For example, a CA-repeat microsatellite in insulin-like growth factor $1(I G F 1)$ promoter is associated with the level of this growth factor. It turned out that intensity of the gene transcription is regulated by the interaction of several SNPs and the microsatellite generating haplotypes with lower or higher level of the gene transcription [70]. The promoter microsatellites tend to be $\mathrm{G} / \mathrm{C}$ rich; these are often found at the start of the genes and are probably associated with regulatory elements as $\mathrm{CpG}$ islands, G-quadruplexes (G4) and untranslated regulatory regions. Many promoter microsatellites have the potential to affect human phenotypes by generating mutations in regulatory elements, which may ultimately result in disease [71]. A CpG-CA repeat within the human endothelin-converting enzyme-1 (ECE-1) promoter is highly polymorphic, harbours transcriptional start sites, it is able to recruit the transcription factors, poly(ADP)ribose polymerase-1 and splicing factors, it is functional regarding haplotype-specific promoter activity. Overall CpG-CA repeat composition of Alzheimer disease patients and controls is distinct [72]. A length polymorphism of GT repeats in the promoter region of the human heme oxygenase-1 (HO- 1$)$ gene modulates its gene 
transcription [73]. A number of studies have associated the human $\mathrm{HO}-1$ gene promoter polymorphisms with a risk of vascular diseases [74]. The persons carrying longer (GT)n repeats in the HMOXI gene (L allele) promoter may have a higher risk of type 2 diabetes [75]. In functional analyses, the HO-1 expression level was significantly reduced in the persons with impaired glucose regulation and T2DM carrying the L/L (GT)n genotype compared to the persons with the S/S genotype [76]. The same microsatellite is associated with susceptibility to cardiovascular complications of the disease. The patients with longer lengths of GT repeats in the heme oxygenase-1 gene promoter exhibit a higher inflammation and oxidative stress. These patients have a higher risk of the long-term cardiovascular events and mortality [77]. A short allele of the same microsatellite might be associated with the abdominal aortic aneurysm [78]. The long (GT)n repeats in the microsatellite polymorphism region of the $H M O X 1$ gene, are associated with the symptomatic malaria [79].

The aldose reductase $(A K R 1 B 1)$ gene promoter harbours a (CA)n microsatellite significantly associated with diabetic retinopathy. The $\mathrm{z}-2$ microsatellite was found to confer risk in type 1 and type 2 diabetes and $z+2$ to confer the protection against diabetic retinopathy in type 2 diabetes regardless of ethnicity $[80,81]$. The haplotypes comprising $\mathrm{S}$ allele of (CCTTT)n repeat in the promoter of NOS2 gene are associated with both hypertension and responsiveness to antihypertensive drug therapy [82]. The same microsatellite is associated also with diabetic retinopathy, as well as the (GT)n promoter repeat in the tumor necrosis factor $\beta$ (TNFB) gene [81].

The promoter microsatellites might be associated also with mental problems, the promoter TA microsatellite repeat in the estrogen receptor alpha gene (ESR 1$)$ is significantly associated with postpartum depression [83]. The arginine vasopressin receptor $1 \mathrm{~A}$ gene $(A V P R 1 A)$ is widely expressed in the brain and is considered to be a key receptor for the regulation of social behavior. The 5'-flanking region polymorphisms in the human AVPRIA, RS3 and RS1 genes show differences in the relative promoter ac- tivity by the length. Shorter repeat alleles of $R S 1$ and $R S 3$ decreased a relative promoter activity in the human neuroblastoma cell line SH-SY5Y. The short allele of RS1 is associated with autism [84].

The CYP11A1 promoter microsatellite (TTTA)n repeat polymorphisms may contribute to increasing susceptibility to the polycystic ovary syndrome risk [85].

5'-UTR microsatellites. Upregulation of ADAM12 , a member of the multifunctional ADAM family of proteins, is linked to cancer, arthritis and cardiac hypertrophy. The gene expression is regulated by a negative regulatory element containing a stretch of dinucleotide-repeat sequence that is able to adopt a Z-DNA conformation and allows the binding of regulatory protein [86].

Signal sequence microsatellites. Some microsatellites are localized in the translated gene areas. Carnosinase contains a D18S880 microsatellite - a leucine triplet repeat in its signal sequence, polymorphism of this site, especially five trinucleotide repeat homozygote, is associated with diabetic nephropathy susceptibility [87]. The human signal transducer and activator of the transcription 6 (STAT6) gene represents one of the most promising candidate genes for asthma and other inflammatory diseases in the chromosomal region 12q13-q24. The gene exon 1 contains a GT repeat upstream the first methionine codon. Allele A4 of the GT repeat polymorphism is associated with an increase in eosinophil cell count [88]. The genotype of (GT)13/15 repeat allele heterozygosity is significantly associated with allergic subjects [89].

Microsatellites of coding regions. Besides trinucleotide expansion diseases characterized mostly by polyglutamine tracts (poly-Q), which cannot be analysed here due to the space limitations, an interesting trinucleotide repeat was identified in the $M I C-A$ gene. The exon 5 microsatellite polymorphism of the $M I C-A$ gene consists of five alleles based on the number of GCT triplet repeat units (alleles A4, A5, A6, and A9) and the presence of an additional nucleotide insertion (allele A5.1). The CGT repeats regulate the number of Ala residues in the protein, the A5.1 leads to a frameshift mutation. 
The exon encodes membrane-binding domain of the protein [90]. The microsatellite alleles are associated with Addison's disease [90], type 1 diabetes mellitus $[91,92,93]$. Some alleles are protective against juvenile idiopathic arthritis [94]. The variations of CAG (Gln) repeats in the androgen receptor gene in physiological limits can alter certain physiological parameters. A shorter AR CAG is associated with low HDL-C and testosterone [95].

Intronic microsatellites. The microsatellites within introns also influence a phenotype, through the means that are not currently understood, this is the cause of numerous associations of the microsatellite repeat polymorphisms with the human diseases. For example, the GAA triplet expansion in the first intron of the $X 25$ gene appears to interfere with transcription, and causes Friedreich Ataxia [96]. The intronic (GT)n(GA)m microsatellite in the HLADRB1 alleles can adopt several non-B conformations in vivo and binds a zinc-dependent regulatory protein [97]. The CT repeat in the first intron of the $i N O S$ gene adopts triplex structure and binds the regulatory proteins PTBP1 and hnRNPK and regulates the gene expression [98]. A repeat polymorphism in the fourth intron of the eNOS gene is linked to hypertension [99]. Subjects having more the CA repeats in the first intron of the type 2 $11 \beta$-hydroxysteroid dehydrogenase gene (HSD11B2) are susceptible to the developing abnormal glucose tolerance [100]. Three microsatellite loci (ATCC)n1, D1S1621, and (ATCC)n2 in the DISC1 gene show a significant association with schizophrenia. The microsatellites occur in intronic sequences in the vicinity of a critical splice junction that gives rise to the expression of DISC1 isoforms [101].

The intronic microsatellite polymorphisms determine susceptibility to certain neoplasia. For examples, the tandem repeats in the first intron of the asparagine synthetase gene are linked to acute lymphoblastic leukemia [102]. The polymorphisms in the CT dinucleotide repeat in the intron 3 of the transcription factor GATA3 gene are associated with the breast cancer risk, women who carry (CT)17 or (CT)18 alleles of the GATA3 gene are at a lower risk of developing breast cancer [103]. The polymorphic dinucleotide CA tandem repeat (ESR2_CA) is located in the intron 5 of estrogen receptor gene 2 . The gene ESR2 (14q23.2) is associated with the breast cancer risk in African women [104].The intronic D19S884 marker A7 allele of the fibrillin 3 gene is associated with the polycystic ovary syndrome [105].

The intronic microsatellites repeats are implicated in the pathogenic mechanisms of several autoimmune diseases. The SLC26A4 gene, involved in the genetic susceptibility of autoimmune thyroid disease, harbours two microsatellites in the introns 10 and 20; longer alleles of these markers appear to be associated with Hashimoto thyroiditis [106].

Polymorphisms present in the first intron of $I F N-\gamma$ may play an important role in the regulation of the immune response, which could have functional consequences for gene transcription. The microsatellite encoding (CA)16 repeats was shown to be significantly associated with the paucibacillary form of lepra compared to multibacillary patients[107]. The microsatellite marker IFNGR2-MS1 located in 50-upstream region of the interferon gamma receptor 2 gene (IFNGR2) shows significant association with tuberculosis [108]. The interleukin -4 gene intron 3 microsatellite polymorphism determines the gene product and resistance to parasitic invasion [109].

One allele of D6S1276 microsatellite in the intron 1 of the BMP5 gene is associated with osteoarthritis risk in women, two alleles are protective [110]. Our team has performed a study on the association of a group of microsatellites localized in the 14q13 locus $[111,112,113]$.

3' - UTR microsatellites. The microsatellites localized in the 3'-UTR regions may affect the final mRNA stability, the localization, the export from the nucleus and the translation efficiency. The androgen receptor CAG repeat polymorphism (AR CAG) affects the receptor transcriptional activity (the shorter repeats the more sensitive AR) and is associated with androgenic parameters and obesity [95]. The conserved regulatory sequences within 3' UTRs and the specific elements binding to them enable the gene expression control at the posttranscriptional level 
and all these processes reflect the actual state of the cell [114]. Shorter alleles of microsatellites in the 3' flanking region of leptin gene, coding for a protein hormone, mainly synthesized in adipocytes, that regulates the food intake and energy expenditure of the body, are significantly associated with hypertension [115]. Reduced repeat lengths in the EGFR gene 3'UTR polyA repeat are linked with osteosarcomas [116]. Microasatellite in the anti-cytotoxic T lymphocyte antigen-4 (CTLA-4) gene (AT)n 3'UTR 104 bp, $106 \mathrm{bp}, 110 \mathrm{bp}$ and $116 \mathrm{bp}$ alleles were observed to be predisposing to recurrent miscarriage [117].

Remote and locus-specific microsatellites. In some cases, an association with the diseases is found for microsatellites localized far from the candidate genes. Microsatellites can determine activity of the upstream gene regulation elements like Locus Control Region of the Beta-globin gene domain. The (AT)8(N)12GT(AT)7 configuration of microsatellite found in the Hypersensitive site of the structure is associated with a special form of sickle cells Tunisian $\beta$ s chromosomes [118]. In some gene clusters the changes in microsatellite structure drastically modify the transcription factor binding and gene switching [119]. The marker D12S96 is localized $5.653 \mathrm{cM}$ downstream the vitamin $\mathrm{D}$ receptor $(V D R)$ gene. Despite such a long distance and obscure functional relations, the statistically significant linkage disequilibrium was detected for the allele -22 of locus D12S96 with osteoporosis [120]. In some cases, an association of microsatellites with candidate genes is not traced at all, as these are sooner locus than gene markers. 8p21-23 region microsatellites D8S136 and D8S520 are consistently and strongly related to prostate cancer, provide the example [121]. The locus was traced due to frequent loss of heterozygosity in tumours, but not as a result of association studies. The D1S2726 microsatellite, located $30 \mathrm{~kb}$ from the KCNA3 gene, which encodes the voltagegated potassium channel Kv1.3, is associated with susceptibility to autoimmune pancreatitis [122].

Conclusion. We hope that all above facts would persuade a reader that association of the microsatellite length with pathologies is a consequence of the structural and functional modification of the genome produced by changes in the repeat length.

\section{Acknowledgements}

The work was funded by the University of Latvia in the frame of the project "Topical clinical and basic investigations in biomedicine and pharmacy".

\section{REFERENCES}

1. King $D G$. Evolution of simple sequence repeats as mutable sites. Adv Exp Med Biol. 2012;769:10-25.

2. Grandi $F C, A n W$. Non-LTR retrotransposons and microsatellites: Partners in genomic variation. Mob Genet Elements. 2013;3(4):e25674.

3. Gulcher J. Microsatellite markers for linkage and association studies. Cold Spring Harb Protoc. 2012;4:425-32.

4. Do-Yup Lee, McMurray CT. Trinucleotide expansion in disease: Why is there a length threshold? Curr Opin Genet Dev 2014;26:131-40.

5. Grzeskowiak K, Ohishi H, Ivanov V. Circular dichroism spectra of d(CGCGCGCGCGCG): evidence for intermediate models in the B-to-Z transition. Nucleic Acids Symp Ser (Oxf). 2005;49:249-50.

6. Vorlícková M, Kejnovská I, Tumová M, Kypr J. Conformational properties of DNA fragments containing GAC trinucleotide repeats associated with skeletal displasias. Eur Biophys J. 2001;30(3):179-85.

7. $L i G$, Tolstonog $G V$, Traub P. Interaction in vitro of type III intermediate filament proteins with Z-DNA and B-Z-DNA junctions. DNA Cell Biol. 2003;22:141-69.

8. Wang $Q$, Li L, Wang $X$, Liu H, Yao X. Understanding the recognition mechanisms of $Z \alpha$ domain of human editing enzyme ADAR1 (hZ $\alpha($ ADAR1)) and various Z-DNAs from molecular dynamics simulation. J Mol Model. 2014;20(11): 2500.

9. Renčiuk D, Kypr J, Vorlíčková M. CGG repeats associated with fragile X chromosome form left-handed Z-DNA structure. Biopolymers. 2011;95(3):174-81.

10. Latha KS, Anitha S, Rao KSJ, Viswamitra MA. Molecular understanding of aluminum-induced topological changes in (CCG)12 triplet repeats: relevance to neurological disorders. Biochim Biophys Acta. 2002;1588(1):56-64

11. Tam M, Erin Montgomery S, Kekis M, Stollar BD, Price GB, Pearson CE. Slipped (CTG).(CAG) repeats of the myotonic dystrophy locus: surface probing with anti-DNA antibodies. J Mol Biol. 2003;332(3):585-600.

12. Wang G, Vasquez KM. Z-DNA, an active element in the genome. Front Biosci. 2007;12:4424-38.

13. Lo YS, Tseng WH, Chuang CY, Hou MH. The structural basis of actinomycin D-binding induces nucleotide flipping 
out, a sharp bend and a left-handed twist in CGG triplet repeats. Nucl. Acids Res. 2013;41(7):4284-94.

14. Liang $D$, Wilusz J E. Short intronic repeat sequences facilitate circular RNA production. Genes Dev. 2014;28(20):2233-47

15. George B, Alam ChM, Kumar RV, Gnanasekaran P, Chakraborty $S$. Potential linkage between compound microsatellites and recombination in geminiviruses: Evidence from comparative analysis. Virology. 2015;482:41-50.

16. Qiu Y, Niu H, Vukovic L, Sung P, Myong S. Molecular mechanism of resolving trinucleotide repeat hairpin by helicases. Structure. 2015;23(6):1018-27.

17. Kejnovská I, Tumová M, Vorlícková M. (CGA)(4): parallel, anti-parallel, right-handed and left-handed homoduplexes of a trinucleotide repeat DNA. Biochim Biophys Acta. 2001;1527(1-2):73-80.

18. Loomis EW, Sanz LA, Chédin F, Hagerman PJ. Transcription-associated R-loop formation across the human FMR1 CGG-repeat region. PLoS Genet. 2014;10(4):e1004294.

19. Asamitsu S, Kawamoto Y, Hashiya F, Hashiya K, Yamamoto $M$, Kizaki S, Bando T, Sugiyama $H$. Sequence-specific DNA alkylation and transcriptional inhibition by long-chain hairpin pyrrole-imidazole polyamide-chlorambucil conjugates targeting $\mathrm{CAG} / \mathrm{CTG}$ trinucleotide repeats. Bioorg Med Chem. 2014;22(17):4646-57.

20. Sjakste T, Poudžiunas I, Pīrāgs V, Lazdiņš M, Sjakste N. Bioinformatic Analysis of Evolutional Conservatism and Functional Significance of Microsatellite Alleles of Human 14Q13.2 Region Associated with Type 2 Diabetes Mellitus. Proceedings of the Latvian Academy of Sciences. 2008;62(3):91-102.

21. Tolstonog GV, Mothes E, Shoeman RL, Traub P. Isolation of SDS-Stable Complexes of the Intermediate Filament Protein Vimentin with Repetitive, Mobile, Nuclear Matrix Attachment Region, and Mitochondrial DNA Sequence Elements from Cultured Mouse and Human Fibroblasts. DNA Cell Biol. 2001;20(9):531-54.

22. Van Hecke K, Uytterhoeven K, Van Meervelt L. Exploration of triple-helical fragments: crystallization and preliminary X-ray diffraction of d(TGGCCTTAAGG). Acta Crystallogr Sect F Struct Biol Cryst Commun. 2007;63(1):52-5.

23. $\mathrm{Li} \mathrm{G}$, Tolstonog GV, Traub P. Interaction in vitro of type III intermediate filament proteins with triplex DNA. DNA Cell Biol. 2003;22(3):141-69.

24. Paris C, Geinguenaud F, Gouyette C, Liquier J, Lacoste J. Mechanism of Copper Mediated Triple Helix Formation at Neutral $\mathrm{pH}$ in Drosophila Satellite Repeats. Biophys J. 2007;92(7):2498-506.

25. Singh $H N$, Rajeswari $M R$. Gene regulation by long purine tracks in brain related diseases. Data in Brief. 2015;5:218-25.

26. Singh HN, Rajeswari MR. Role of long purine stretches in controlling the expression of genes associated with neurological disorders. Gene. 2015;572(2):175-83.

27. LeProust EM, Pearso CE, Sinden RR, Gao X. Unexpected formation of parallel duplex in GAA and TTC trinucleo- tide repeats of Friedreich's Ataxia. JMol Biol. 2000;302(5): 1063-80.

28. Li YY, Abu-Ghazalah R, Zamiri B, Macgregor RB Jr. Concentration-dependent conformational changes in GQ-forming ODNs. Biophys Chem. 2016;211:70-5.

29. D Koirala, C Ghimire, C Bohrer, SannoheY, Sugiyama H, Mao $H$. Long-loop G-quadruplexes are misfolded population minorities with fast transition kinetics in human telomeric sequences. J Am Chem Soc. 2013;135(6):2235-41.

30. Jin SF; Zhao P; Xu L; Zheng M; Lu J; Zhao P; Su Q; Chen H; Tang D; Chen J; Lin J. Synthesis, G-quadruplexes DNA binding, and photocytotoxicity of novel cationic expanded porphyrins. Bioorg Chem. 2015;60:110-7.

31. Šket P, Pohleven J, Kovanda A, Štalekar M, Župunski V, Zalar $M$, Plavec J, Rogelj B. Characterization of DNA G-quadruplex species forming from C9ORF72 G4C2-expanded repeats associated with amyotrophic lateral sclerosis and frontotemporal lobar degeneration. Neurobiol Aging. 2015; 36(2):1091-6.

32. Zhou B, Liu C, Geng Y, Zhu G. Topology of a G-quadruplex DNA formed by $\mathrm{C} 9$ orf72 hexanucleotide repeats associated with ALS and FTD. Sci Rep. 2015;5:16673.

33. Vatovec S, Kovanda A, Rogelj B. Unconventional features of C9ORF72 expanded repeat in amyotrophic lateral sclerosis and frontotemporal lobar degeneration. Neurobiol Aging. 2014;35(10):2421.e1-12.

34. Chen $Y W$, Jhan $C R$, Neidle S, Hou MH. Structural Basis for the Identification of an i-Motif Tetraplex Core with a Parallel-Duplex Junction as a Structural Motif in CCG Triplet Repeats. Angew Chem Int Ed Engl. 2014;53(40):10682-6.

35. Lexa M, Kejnovský E, Steflová P, Konvalinová H, Vorlícková $M$, Vyskot B. Quadruplex-forming sequences occupy discrete regions inside plant LTR retrotransposons. Nucleic Acids Res. 2014;42(2):968-78.

36. Phan AT, Modi YS, Patel DJ. Propeller-Type ParallelStranded G-Quadruplexes in the Human c-myc Promoter. $J$ Am Chem Soc. 2004;126(28):8710-6.

37. $W u$ Y, Brosh RM Jr. G-quadruplex nucleic acids and human disease. FEBS J. 201;277(17):3470-88.

38. Tolstonog GV, Li G, Shoeman RL, Traub P. Interaction in vitro of type III intermediate filament proteins with higher order structures of single-stranded DNA, particularly with G-quadruplex DNA. DNA Cell Biol. 2005;24:85-110.

39. Dion $V$, Wilson $J H$. Instability and Chromatin Structure of Expanded Trinucleotide Repeats. Trends Genet. 2009;25(7): 288-97

40. Iyer RR, Pluciennik A, Napierala M, Wells RD. DNA Triplet Repeat Expansion and Mismatch Repair. Annu Rev Biochem. 2015;84:199-226.

41. Chutake YK, Costello WN, Lam C, Bidichandani SI. Altered Nucleosome Positioning at the Transcription Start Site and Deficient Transcriptional Initiation in Friedreich Ataxia. J Biol Chem. 2014;289(22):15194-202. 
42. Zhao H; Xing Y; Liu G; Chen P; Zhao X; Li G; Cai L. GAA triplet-repeats cause nucleosome depletion in the human genome. Genomics. 2015;106(2):88-95.

43. Ruan H, Wang YH. Friedreich's ataxia GAA.TTC duplex and GAA.GAA.TTC triplex structures exclude nucleosome assembly. J Mol Biol. 2008;383(2):292-300.

44. Volle $C B$, Delaney $S$. CAG/CTG Repeats Alter Affinity for the Histone Core and Positioning of DNA in the Nucleosome. Biochemistry. 2012;51(49):9814-25.

45. Arope S, Harraghy N, Pjanic M, Mermod N. Molecular Characterization of a Human Matrix Attachment Region Epigenetic Regulator. PLoS ONE. 2013;8(11):e79262.

46. Boulikas T. Nature of DNA sequences at the attachment regions of genes to the nuclear matrix. J Cell Biochem. 1993; 52:14-22.

47. Lenartowski R, Goc A. Tissue-specific association of the human tyrosine hydroxylase gene with the nuclear matrix. Neurosci Lettr. 2002;330:151-54.

48. Silva AM, Brown JM, VJ Buckle, Wade-Martins R, Lufino $M M P$. Expanded GAA repeats impair FXN gene expression and reposition the FXNlocus to the nuclear lamina in single cells. Hum. Mol. Genet.2015;24(12):3457-71.

49. Petrov A, Pirozhkova I, Carnac G, Laoudj D, Lipinski M, Vassetzky YS. Chromatin loop domain organization within the $4 \mathrm{q} 35$ locus in facioscapulohumeral dystrophy patients versus normal human myoblasts. Proc Natl Acad Sci USA. 2006;103(18):6982-7.

50. Kisseljova NP, Dmitriev P, Katargin A,Kim E, Ezerina D, MarkozashviliD, Malysheva D, Planche E, Lemmers RJLF, $S M$ van der Maarel, Laoudj-Chenivesse D, Lipinski $M$ and Vassetzky YS. DNA polymorphism and epigenetic marks modulate the affinity of a scaffold/matrix attachment region to the nuclear matrix. Eur J Hum Genet. 2014;22:1117-23.

51. Zheng R, Shen Z, Tripathi V, Xuan Z, Freier SM, Bennett CF, Prasanth $S G$, Prasanth $K V$. Polypurine-repeat-containing RNAs: a novel class of long non-coding RNA in mammalian cells. J Cell Sci. 2010;123(Pt 21):3734-44

52. Filippova GN, Thienes CP, Penn BH, Cho DH, Hu YJ, Moore JM, Klesert TR, Lobanenkov VV, Tapscott SJ. CTCFbinding sites flank CTG/CAG repeats and form a methylation-sensitive insulator at the DM1 locus. Nature Genet. 2001;28:335-43.

53. Rothenburg $S$, Koch-Nolte F, Haag F. DNA methylation and Z-DNA formation as mediators of quantitative differences in the expression of alleles. Immunol Rev. 2001;184:286-298.

54. Bassuny WM, Ihara K, Sasaki Y, Kuromaru R, Kohno H, Matsuura, N, Hara T. A functional polymorphism in the promoter/enhancer region of the FOXP3/Scurfin gene associated with type 1 diabetes. Immunogenetics. 2003;55: 149-56.

55. Kumar RP, Krishnan J, Singh NP, Singh L, Mishra RK.GATA simple sequence repeats function as enhancer blocker boundaries. Nat Commun. 2013;4:1844.
56. Nelson DL, Orr HT, Warren ST. The unstable repeats--three evolving faces of neurological disease. Neuron. 2013;77(5): 825-43.

57. Yamamoto, $H \&$ Imai, $K$. Microsatellite instability: an update. Arch Toxicol. 2015;89:899.

58. Heidari A, Nariman Saleh Fam Z, Esmaeilzadeh-Gharehdaghi E, Banan M, Hosseinkhani S, Mohammadparast S, Oladnabi M, Ebrahimpour MR, Soosanabadi M, Farokhashtiani T. et al. Core promoter STRs: novel mechanism for inter-individual variation in gene expression in humans. Gene. 2012;492(1):195-8.

59. Valipour E, Kowsari A, Bayat H, Banan M, Kazeminasab S, Mohammadparast S, Ohadi M. Polymorphic core promoter GA-repeats alter gene expression of the early embryonic developmental genes. Gene. 2013;531(2):175-9.

60. Chen YS, Racca JD, Sequeira PW, Phillips NB, Weiss MA. Microsatellite-encoded domain in rodent Sry functions as a genetic capacitor to enable the rapid evolution of biological novelty. Proc Natl Acad Sci U S A. 2013;110(33):E3061-70.

61. Sawaya SM, Bagshaw AT, Buschiazzo E, Gemmell NJ. Promoter microsatellites as modulators of human gene expression. Adv Exp Med Biol. 2012;769:41-54.

62. Sawaya SM, Lennon D, Buschiazzo E, Gemmell N, Minin $V N$. Measuring microsatellite conservation in mammalian evolution with a phylogenetic birth-death model. $\mathrm{Ge}$ nome Biol Evol. 2012;4(6):636-47.

63. Taka S, Gazouli M, Politis PK, Pappa KI, Anagnou NP. Transcription factor ATF-3 regulates allele variation phenotypes of the human SLC11A1 gene. Mol Biol Rep. 2013;40(3):2263-71.

64. García SI, Porto PI, Dieuzeide G, Landa MS, Kirszner T, Plotquin Y, Gonzalez C, Pirola CJ. Thyrotropin-releasing hormone receptor (TRHR) gene is associated with essential hypertension. Hypertension. 2001;38(3 Pt 2):683-7.

65. Bayele HK, Peyssonnaux C, Giatromanolaki A, Arrais-Silva WW, Mohamed HS, Collins H, Giorgio S, Koukourakis M, Johnson RS, Blackwell JM, Nizet V, Srai SK. HIF-1 regulates heritable variation and allele expression phenotypes of the macrophage immune response gene SLC11A1 from a Z-DNA forming microsatellite. Blood. 2007;110(8): 3039-48.

66. Johnson MP, Lea RA, Colson NJ, Macmillan JC, Griffiths $L R$. A population genomics overview of the neuronal nitric oxide synthase (nNOS) gene and its relationship to migraine susceptibility. Cell Mol Biol (Noisy-le-grand). 2005;51(3):285-92.

67. Rothenburg $S$, Koch-Nolte F, Rich A, Haag F. A polymorphic dinucleotide repeat in the rat nucleolin gene forms ZDNA and inhibits promoter activity. Proc Natl Acad Sci USA. 2001;98(16):8985-90.

68. Tanaka G, Matsushita I, Ohashi J, Tsuchiya N, Ikushima S, Oritsu M, Hijikata M, Nagata T, Yamamoto K, Tokunaga K, Keicho N. Evaluation of microsatellite markers in associa- 
tion studies: a search for an immune-related susceptibility gene in sarcoidosis. Immunogenetics. 2005;56(12):861-70.

69. Rockman $M V$, Wray GA. Abundant raw material for cis-regulatory evolution in humans. Mol Biol Evol. 2002;19(11): 1991-2004.

70. Chen HY, Huang $W$, Leung VH, Fung SL, Ma SL, Jiang H, Tang NL. Functional interaction between SNPs and microsatellite in the transcriptional regulation of insulin-like growth factor 1. Hum Mutat. 2013;34(9):1289-97.

71. Sawaya S, Bagshaw A, Buschiazzo E, Kumar P, Chowdhury $S$, Black MA, Gemmell N. Microsatellite tandem repeats are abundant in human promoters and are associated with regulatory elements. PLoS One. 2013;8(2):e54710.

72. Li Y, Seidel K, Marschall P, Klein M, Hope A, Schacherl J, et al. A polymorphic microsatellite repeat within the ECE1c promoter is involved in transcriptional start site determination, human evolution, and Alzheimer's disease. J Neurosci. 2012;32(47):16807-20.

73. Hu YF, Lee KT, Wang HH, Ueng KC, Yeh HI, Chao TF et al. The association between heme oxygenase-1 gene promoter polymorphism and the outcomes of catheter ablation of atrial fibrillation. PLoS One. 2013;8(2):e56440.

74. Wu ML, Ho YC, Yet SF. A central role of heme oxygenase-1 in cardiovascular protection. Antioxid Redox Signal. 2011; 15(7):1835-46.

75. Bao W, Song F, Li X, Rong S, Yang W, Wang D, Xu J, Fu J, Zhao Y, Liu L. Association between heme oxygenase-1 gene promoter polymorphisms and type 2 diabetes mellitus: a HuGE review and meta-analysis. Am J Epidemiol. 2010; 172(6):631-6.

76. Song F, Li X, Zhang M, Yao P, Yang N, Sun X, Hu FB, Liu L. Association between heme oxygenase-1 gene promoter polymorphisms and type 2 diabetes in a Chinese population. Am J Epidemiol. 2009;170(6):747-56.

77. Chen YH, Hung SC, Tarng DC. Length polymorphism in heme oxygenase-1 and cardiovascular events and mortality in hemodialysis patients. Clin J Am Soc Nephrol. 2013;8(10): 1756-63.

78. Gregorek AC, Gornik KC, Polancec DS, Dabelic S. GT microsatellite repeats in the heme oxygenase-1 gene promoter associated with abdominal aortic aneurysm in Croatian patients. Biochem Genet. 2013;51(5-6):482-92.

79. Mendonça VR, Luz NF, Santos NJ, Borges VM, Gonçalves $M S$, Andrade BB, Barral-Netto $M$. Association between the haptoglobin and heme oxygenase 1 genetic profiles and soluble CD163 in susceptibility to and severity of human malaria. Infect Immun. 2012;80(4):1445-54.

80. Abhary S, Hewitt AW, Burdon KP, Craig JE. A systematic meta-analysis of genetic association studies for diabetic retinopathy. Diabetes. 2009;58(9):2137-47.

81. Uthra S, Raman R, Mukesh BN, Rajkumar SA, Kumari P, Lakshmipathy P, Gnanamoorthy P, Sharma T, McCarty CA, Kumaramanickavel $G$. Diabetic retinopathy: Validation study of ALR2, RAGE, iNOS and TNFB gene variants in a south Indian cohort. Ophthalmic Genet. 2010;31(4):244-51.

82. Oliveira-Paula GH, Lacchini R, Coeli-Lacchini FB, Junior $H M$, Tanus-Santos JE. Inducible nitric oxide synthase haplotype associated with hypertension and responsiveness to antihypertensive drug therapy. Gene. 2013;515(2):391-5.

83. Pinsonneault JK, Sullivan D, Sadee W, Soares CN, Hampson $E$, Steiner $M$. Association study of the estrogen receptor gene ESR1 with postpartum depression-a pilot study. Arch Womens Ment Health. 2013;16(6):499-509.

84. Tansey KE, Hill MJ, Cochrane LE, Gill M, Anney RJ, Gallagher L. Functionality of promoter microsatellites of arginine vasopressin receptor 1A (AVPR1A): implications for autism. Mol Autism. 2011;2(1):3.

85. Shen $W, L i T, H u$ Y, Liu H, Song M. Common polymorphisms in the CYP1A1 and CYP11A1 genes and polycystic ovary syndrome risk: a meta-analysis and meta-regression. Arch Gynecol Obstet. 2014;289(1):107-18

86. Ray BK, Dhar S, Shakya A, Ray A. Z-DNA-forming silencer in the first exon regulates human ADAM-12 gene expression. Proc Natl Acad Sci U S A. 2011;108(1):103-8.

87. Zhu JM, Wang B, Li J, Chen GM, Fan YG, Feng CC, Pan HF, Ye DQ. D18S880 microsatellite polymorphism of carnosinase gene and diabetic nephropathy: a meta-analysis. Genet Test Mol Biomarkers. 2013;17(4):289-94.

88. Duetsch G, Illig T, Loesgen S, Rohde K, Klopp N, Herbon N, Gohlke H, Altmueller J, Wjst M. STAT6 as an asthma candidate gene: polymorphism-screening, association and haplotype analysis in a Caucasian sib-pair study. Hum Mol Genet. 2002;11(6):613-21.

89. Tamura K, Suzuki M, Arakawa H, Tokuyama K, Morikawa $A$. Linkage and association studies of STAT6 gene polymorphisms and allergic diseases. Int Arch Allergy Immunol. 2003;131(1):33-8.

90. Gambelunghe G, Falorni A, Ghaderi M, Laureti S, Tortoioli C, Santeusanio F, Brunetti P, Sanjeevi CB. Microsatellite polymorphism of the MHC class I chain-related (MIC-A and MIC-B) genes marks the risk for autoimmune Addison's disease. J Clin Endocrinol Metab. 1999;84(10):3701-7.

91. Kumar N, Sharma G, Kaur G, Tandon N, Bhatnagar $S$, Mehra N. Major histocompatibility complex class I chain related gene-A microsatellite polymorphism shows secondary association with type 1 diabetes and celiac disease in North Indians. Tissue Antigens. 2012;80(4):356-62.

92. Novota P, Kolostova K, Pinterova D, NovakJ, Weber P, Treslova L, Kovar J, Andel M, Cerna M. Association of MHC class I chain related gene-A microsatellite polymorphism with the susceptibility to T1DM and LADA in Czech adult patients. Int J Immunogenet. 2005;32(5):273-5.

93. Bilbao JR, Martín-Pagola A, Calvo B, Perez de Nanclares $G$, Gepv-N, Castaño L. Contribution of MIC-A polymorphism to type 1 diabetes mellitus in Basques. Ann NY Acad Sci. 2002;958:321-4. 
94. Nikitina Zake L, Cimdina I, Rumba I, Dabadghao P, Sanjeevi $C B$. Major histocompatibility complex class I chain related (MIC) A gene, TNFa microsatellite alleles and TNFB alleles in juvenile idiopathic arthritis patients from Latvia. Hum Immunol. 2002;63(5):418-23.

95. Stanworth RD, Kapoor D, Channer KS, Jones TH. Dyslipidaemia is associated with testosterone, oestradiol and androgen receptor CAG repeat polymorphism in men with type 2 diabetes. Clin Endocrinol (Oxf). 2011;74(5):624-30.

96. Bidichandani SI, Ashizawa T, Patel PI. The GAA tripletrepeat expansion in Friedreich ataxia interferes with transcription and may be associated with an unusual DNA structure. Am J Hum Genet. 1998;62(1):111-21.

97. Mäueler W, Bassili G, Arnold R, Renkawitz R, Epplen JT. The (gt)n(ga)m containing intron 2 of HLA-DRB alleles binds a zinc-dependent protein and forms non B-DNA structures. Gene. 1999;226(1):9-23.

98. Motallebipour M, Rada-Iglesias A, Westin G, Wadelius $C$. Two polypyrimidine tracts in the nitric oxide synthase 2 gene: similar regulatory sequences with different properties. Mol Biol Rep. 2010;37(4):2021-30.

99. Jemaa R, Ben Ali S, Kallel A, Feki M, Elasmi M, Taieb SH, Sanhaji H, Omar S, Kaabachi N. Association of a 27-bp repeat polymorphism in intron 4 of endothelial constitutive nitric oxide synthase gene with hypertension in a Tunisian population. Clin Biochem. 2009;42(9):852-6.

100. Mune T, Suwa T, Morita H, Isomura Y, Takada N, Yamamoto $Y$ et al. Longer HSD11B2 CA-repeat in impaired glucose tolerance and type 2 diabetes. Endocr J. 2013;60(5): 671-8.

101. Cao F, Zhang H, Feng J, Gao C, Li S. Association study of three microsatellite polymorphisms located in introns 1,8 , and 9 of DISC1 with schizophrenia in the Chinese Han population. Genet Test Mol Biomarkers. 2013;17(5):407-11.

102. Akagi T, Yin D, Kawamata N,Bartram CR, Hofmann WK, Song JH, Miller CW, den Boer ML, Koeffler HP. Functional analysis of a novel DNA polymorphism of a tandem repeated sequence in the asparagine synthetase gene in acute lymphoblastic leukemia cells. Leuk Res. 2009;33(7):991-6.

103. Zakieh A, Simin H, Forousan S, Manoochehr T. Polymorphic CT dinucleotide repeat in the GATA3 gene and risk of breast cancer in Iranian women. Med Oncol. 2013;30(2):504.

104. Zheng Y, Huo D, Zhang J, Yoshimatsu TF, Niu Q, Olopade OI. Microsatellites in the estrogen receptor (ESR1, ESR2) and androgen receptor (AR) genes and breast cancer risk in African American and Nigerian women. PLoS One. 2012;7(7):e40494.

105. Xie GB, Xu P, Che YN, Xia YJ, Cao YX, Wang WJ, Qiao D, Wu XK, Yi L, Gao Q, Wang Y. Microsatellite polymorphism in the fibrillin 3 gene and susceptibility to PCOS: a casecontrol study and meta-analysis. Reprod Biomed Online. 2013;26(2):168-74.

106. Belguith-Maalej S, Kallel R, Mnif M, Abid M, Ayadi $H$, Kacem HH. Association of intronic repetition of SLC26A4 gene with Hashimoto thyroiditis disease. Genet Res (Camb). 2013;95(1):38-44.

107. Silva GA, Santos MP, Mota-Passos I, Boechat AL, Malheiro $A$, Naveca $F G$, de Paula $L$. IFN- $\gamma+875$ microsatellite polymorphism as a potential protection marker for leprosy patients from Amazonas state, Brazil. Cytokine. 2012;60(2): 493-7

108. Hijikata M, Shojima J, Matsushita I, Tokunaga K, Ohashi J, Hang NT, Horie T, Sakurada S, Hoang NP, Thuong PH, Lien LT, Keicho N. Association of IFNGR2 gene polymorphisms with pulmonary tuberculosis among the Vietnamese. Hum Genet. 2012;131(5):675-82.

109. Mendonça MS, Peraçolli TS, Silva-Vergara ML, et al. High interleukin-4 expression and interleukin-4 gene polymorphisms are associated with susceptibility to human paracoccidioidomycosis. Memórias do Instituto Oswaldo Cruz. 2015;110(6):781-5.

110. Rodriguez-Fontenla C, Carr A, Gomez-Reino JJ, Tsezou A, Loughlin J, Gonzalez A. Association of a BMP5 microsatellite with knee osteoarthritis: case-control study. Arthritis Res Ther. 2012;14(6):R257.

111. Sjakste T, Eglite J, Sochnevs A, Marga M, Pirags V, Collan Y, Sjakste $N$. Microsatellite genotyping of chromosome $14 \mathrm{q} 13.2-14 \mathrm{q} 13$ in the vicinity of proteasomal gene PSMA6 and association with Graves' disease in the Latvian population. Immunogenetics. 2004;56(4):238-43.

112. Sjakste T, Kalis M, Poudziunas I, Pirags V, Lazdins M, Groop L, Sjakste N. Association of microsatellite polymorphisms of the human 14q13.2 region with type 2 diabetes mellitus in Latvian and Finnish populations. Ann Human Genet. 2007;71:772-6.

113. Sjakste T, Trapina I, Rumba-Rozenfelde I, Lunin R, Sugoka $\mathrm{O}$, Sjakste $N$. Identification of a Novel Candidate Locus for Juvenile Idiopathic Arthritis at 14q13.2 in the Latvian Population by Association Analysis with Microsatellite Markers. DNA Cell Biol. 2010;29:543-51.

114. Michalova E, Vojtesek B, Hrstka R. Impaired pre-mRNA processing and altered architecture of 3 ' untranslated regions contribute to the development of human disorders. Int J Mol Sci. 2013;14(8):15681-94.

115. Akhter Q, Masood A, Ashraf R, Majid S, Rasool S, Khan T, Rashid T, Sameer AS, Ganai BA. Polymorphisms in the 3'UTR of the human leptin gene and their role in hypertension. Mol Med Rep. 2012;5(4):1058-62.

116. Kersting C, Agelopoulos K, Schmidt H, Korsching E, August $C$, Gosheger G, Dirksen U, Juergens H, Winkelmann W, Brandt B, Bielack S, Buerger H, Gebert C. Biological importance of a polymorphic CA sequence within intron 1 of the epidermal growth factor receptor gene (EGFR) in high grade central osteosarcomas. Genes Chromosomes Cancer. 2008;47(8):657-64.

117. Gupta R, Prakash S, Parveen F, Agrawal S. Association of CTLA-4 and TNF- $\alpha$ polymorphism with recurrent miscar- 
riage among North Indian women. Cytokine. 2012;60(2): 456-62.

118. Ben Mustapha M, Moumni I, Zorai A, Douzi K, Ghanem A, Abbes $S$. Microsatellite and single nucleotide polymorphisms in the $\beta$-globin locus control region-hypersensitive Site 2: SPECIFICITY of Tunisian $\beta$ s chromosomes. Hemoglobin. 2012;36(6):533-44.

119. José-Edwards DS, Oda-Ishii I, Kugler JE, Passamaneck YJ, Katikala L, Nibu Y, Di Gregorio A. Brachyury, Foxa2 and the cis-Regulatory Origins of the Notochord. PLoS Genet. 2015;11(12):e1005730.

120. Raje M, Botre C, Ashma R. Genetic epidemiology of osteoporosis across four microsatellite markers near the VDR gene. Int J Mol Epidemiol Genet. 2013;4(2):101-8.

121. Zeegers MP, Nekeman D, Khan HS, van Dijk BA, Goldbohm RA, Schalken J, Shajahan S, Pearlman A, Oddoux C, van den Brandt PA, Schouten LJ, Ostrer H. Prostate cancer susceptibility genes on $8 \mathrm{p} 21-23$ in a Dutch population. Prostate Cancer Prostatic Dis. 2013;16(3):248-53.

122. Ota M, Ito T, Umemura T, Katsuyama Y, Yoshizawa K, Hamano H, Kawa S. Polymorphism in the KCNA3 gene is associated with susceptibility to autoimmune pancreatitis in the Japanese population. Dis Markers. 2011;31(4):223-9.

\section{Структурно-функціональне значення мікросателітних повторів ДНК}

Т. Сьяксте, Н. Парамонова, Н. Сьяксте

Огляд узагальнює дані літератури про вплив мікросателітних повторів на структуру ДНК і хроматину та результати досліджень щодо зв'язку між довжиною мікросателітних повторів і схильныстю до патологій. У мікросателітних сайтах змінюється вторинна структура ДНК, загальна структура і організація петлі хроматину; повтори сприяють утворенню Z-ДНК, шпильок, триплексів і квадруплексов. Дані досліджень по асоціаціям класифікують по локалізації мікросателітів: у промоторі гена, в області першого екзона, що кодує сигнальну послідовність, в інтронній т частини, та в кодуючий в 3'-UTR ділянках гена.

К л ю ч о в і с л о в а: микросателітні повтори ДНК, хроматин, хвороби людини, промотор, інтрон, екзон

\section{Структурно-функциональное значение микросателлитных повторов ДНК}

Т. Сьяксте, Н. Парамонова, Н. Сьяксте

Обзор обобщает данные литературы о влиянии микросателлитных повторов на ДНК и структуру хроматина и положительные результаты исследований связи между длиной микросателлитных повторов и предрасположенности к патологиям. В микросателлитных сайтах изменяется вторичная структура ДНК, общая структура и организация петли хроматина; повторы способствуют образованию Z-ДНК, шпилек, триплексов и квадруплексов. Данные исследований по ассоциациям классифицируются по локализации микросателлитов: в промоторе гена, в области первого экзона кодирующей сигнальную последовательность, в интронной части, в кодирующих и в 3'UTR областях гена.

К л ю ч е в ы е с л о в а: микросателлитные повторы ДНК, хроматин, болезни человека, промотор, интрон, экзон

Received 15.08.2016 